\title{
A Comparative Analysis of the Pronunciation of Engineers and Bureaucrats: An
}

\section{Explanatory Research}

* Afshan, PhD Scholar (Corresponding Author)

** Dr. Sikandar Ali, Assistant Professor

*** Anum Saeed, MPhil

\begin{abstract}
It is a fact that English has become part and parcel of our society. All the fields of our society have been affected by English in the modern epoch. Major important issues pertaining to English language teaching are still unanswered because of lack of strategy for teaching English in our educational institutes. Similarly, pronunciation is one of the major factors, which ruins the image of a speaker, although he or she is good in grammatical and other features of English language. The purpose of instant study is to find out the reasons behind mispronunciation of English language in our society. For this purpose, two types of important professional fields of our society were taken up for experiment, which were bureaucrat and engineer. Similarly, two types of research tools were adopted, first was an Observation Sheet and second was structured open-ended questionnaire. The results show different aspects of both targeted groups. It was revealed by the research that bureaucrats are in favour of going with correct pronunciation, whereas engineers are not as enthusiastic to be corrected in pronunciation as bureaucrats.
\end{abstract}

Keywords: Comparative Analysis, Pronunciation, Engineers and Bureaucrats, Explanatory

Introduction

Research, Importance of Pronunciation.

It is irksome for foreign speakers to cope with the pronunciation of the English language as there are not only Grammar and Vocabulary, which build a good English language but pronunciation also plays vital role in the matter. There is no single iota of doubt in the fact that pronunciation is as important to learn any language as skin to the human body because skin is a very crucial part of the body, without it, a human body cannot survive; same is the case with pronunciation. Instead of a good grip of grammar and vocabulary, no foreign speaker can speak English in good and effective manner without true pronunciation. Therefore, the purpose of the study is not only to target the mispronunciation of the English words but also to find out as to how engineers and bureaucrats look at the pronunciation of English. The study also explores the vision of non-native English speakers as to why they are reluctant towards correct pronunciations of English words or if they are keen to learn true pronunciation. Unfortunately, correct pronunciation is nowadays not a common teaching approach and this aspect of English language is often being omitted in our educational institutes from initial to post graduate level.

\section{Research Objective}

The major objective of the research is to explore the reaction of Pakistani engineers and bureaucrats for making English in trouble due to speaking, especially in pronunciation. One of the most crucial aims of this research article is to analyse the genuine approach of Engineer \& Bureaucrat towards English with reference to English speaking and pronunciation.

\section{Research Question}

- How do the Civil Engineers and Bureaucrats pronounce English words with respect to their fields?

- Why are the non-native English speakers reluctant towards correct pronunciation?

- What are the new trends occurring towards learning the pronunciation of English language?

\footnotetext{
* UOL Email: afshanacademia@gmail.com

** UOL Email: Sikandar.ali@ell.uol.edu

*** UOL Email: $\underline{\text { Pakistaninin47@gmail.com }}$
} 


\section{Significance of this Study}

Pronunciation is an important factor and performs a significant role because the way in which we speak portrays our identities and indicates our alliance to specific communities. For an educated class, correct pronunciation during job interviews, presentations, job demonstrations, negotiation, business communication and other professional seminars is essential to ensure their success in the desired field of life. For students, pronunciation errors can be catastrophic especially when they make presentations and oral reports in various subjects in the higher education classrooms. Due to wrong pronunciation, the first negative impact may spoil the career of the affected person because, although a participant has a brilliant score in academic record, may fail to achieve target due to wrong or inappropriate pronunciation.

It is pertinent to mention that, through this research article, we will be aware of new trends occurring towards learning the pronunciation of English language. By the end of this study, we will be able to know how the pronunciation of English language impacts the Engineer and Bureaucrat of our society. One of the most important factors to conduct this research is to trace out the facets, which build such blunders among English speakers in Pakistan.

\section{Delimitation}

The research was based on a selected population from the Civil Administrative Office of Punjab Province, Pakistan.

\section{Literature Review}

Importance of English is great not only in Pakistan but all over the world. It is spoken by more than three hundred \& forty million people as a first language in United Kingdom and US (Crystal, 1997).

"It is a matter of great concern that even when studying English from the primary level, the Pakistani college and university students are unable to communicate effectively in English" (Esmail, Ahmed, \& Noreen., May 2015) English pronunciation is one of the most difficult skills to acquire and learners should spend lots of time to improve their pronunciation (Aliaga García, 2007; Martínez-Flor et al. 2006; Pourhosein Gilakjani, 2016)

Perusal of these statements explores the vitality of English Language, which is paving the way for its need all over the world; accordingly, Pakistan is one of the countries, that is blindly adopting English language in order to run the on track of success in this world. It is very bitter to admit the prevailing concern in our society that people of Pakistan are unable to do fair with English language while oral communication. A lot of blunders have been assumed to be true in the form of wrong pronunciation and people do not hesitate to mispronounce various words as they are unaware of the true phonological structure of words.

It is a great dilemma that students feel reluctant to speak English. It is also true that teachers also emphasize on speaking English but our education system is not supporting this effort at all. That's why students feel great difficulty in speaking English at postgraduate level (Sharma, 2004).

"Good pronunciation is a batch of good language proficiency. Pronunciation teaching is an area that needs the attention of the teachers and the policy makers and syllabus designers. The learners have to face a lot of problems in learning English pronunciation" (Akram \& Qureshi, 2014)

As it is observed that poor pronunciation is a hurdle which makes a student less social, dull in academics (Fraster, 2000). So, it is here to pinpointed that mispronunciation does not only make incapable student in speaking but also affects upon his psyche, which disturbs his social life as well due to disappointment and fear of mispronounced of word. It is also noticed by Dan that good pronunciation may make the communication more relaxed and easier and make it successful (Dan, 2006). According to James (2010), acceptable pronunciation can be understood based on the following basic levels. In level 1, what the speaker is saying is not understandable to people. The speaker uses the wrong sounds when producing English words or uses the wrong prosodic features when producing English sentences. According to Hinofotis and Bailey (1980, as cited in CelceMurcia \& Goodwin, 1991)

Many foreign English speakers, who are well aware of grammar, syntax \& vocabulary, are reluctant to communicate in oral English because of lack of confidence and knowledge of true pronunciation. Here, it is to be cleared that the problem is not only lack of knowledge but the education system, at mediocre as well as low level, is not sufficient enough to encourage the English speaker to cope with this issue. However, this research paper will explore the ways, which are the 
main hindrance in true pronunciation as it is only the major component, which plays a vital role in fluency of speaking.

\section{Methodology \& Techniques}

A proper amalgamation of both qualitative and quantitative research methods was utilized to obtain the purpose, which included questionnaire i.e. structured open-ended questions, closed-ended questions. Survey was conducted in order to get samples of selected populations through questionnaires. Data was analysed on excel sheets with the help of graphs and tables by comparing the words pronounced by Bureaucrat and Technocrat in order to answer the research question.

\section{Participants}

The population was bifurcated into two major categories; the first one was bureaucrats and second one was technocrats i.e. Engineers. 25 participants of each class were taken as representatives and samples were collected from them in the form of structured open-ended and close-ended questionnaires to achieve the purpose, which ultimately came to 50 participants in total. The gender discrimination was highly observed and equality, while obtaining sample, was strictly maintained as much as possible in order to get fair and genuine results.

\section{Data Analysis}

It is a universally recognized truth that Data Analysis is one of significant and crucial facets of any type of research. However, it depends upon data, which is collected from the targeted population by using different available and appropriate tools of sampling for desired research. In a structured closeended questionnaire, participants were requested to pronounce the eleven words from the sheet individually accordingly, transcriptions of each word as spoken by the participants were recorded in column against each spoken word in order to check pronunciation of the words. In a structured openended questionnaire, participants were requested in an easy and more genuine way to answer the question for authentic data collection. After collection of data, it was analysed purely on the basis of answers of the population elected for study by explaining with tables and graphs.

\section{Data Analysis of Close-ended Ques tionnaire}

Table-I is a detailed breakup of Observations Sheet taken from 25 No. Bureaucrats:

\begin{tabular}{|c|c|c|c|c|}
\hline SR. NO. & WORDS & NO. OF CORRECT PRONUNCIATION & $\begin{array}{lc}\text { NO. } & \text { OF } \\
\text { PRONUNCIATION }\end{array}$ & WRONG \\
\hline 1. & Refer & 20 & 5 & \\
\hline 2. & Quote & 12 & 13 & \\
\hline 3. & Almond & 13 & 12 & \\
\hline 4. & Pizza & 18 & 7 & \\
\hline 5. & Grotesque & 15 & 15 & \\
\hline 6. & Genera & 12 & 13 & \\
\hline 7. & Of & 22 & 3 & \\
\hline 8. & Chemise & 5 & 20 & \\
\hline 9. & Womb & 20 & 5 & \\
\hline 10. & Niche & 8 & 17 & \\
\hline 11. & Chassis & 16 & 9 & \\
\hline
\end{tabular}

Table-II is for detailed breakup of Observations Sheet taken from 25 No. Engineers:

\begin{tabular}{clllll}
\hline SR. NO. & \multirow{2}{*}{ WORDS } & $\begin{array}{l}\text { NO. } \\
\text { PRONUNCIATION }\end{array}$ & $\begin{array}{r}\text { OF } \\
\text { CORRCT }\end{array}$ & $\begin{array}{l}\text { NO. } \\
\text { PRONUNCIATION }\end{array}$ & WRONG \\
\hline $\mathbf{1 .}$ & Refer & 10 & 15 \\
$\mathbf{2 .}$ & Quote & 6 & 19 \\
$\mathbf{3 .}$ & Almond & 4 & 21 & \\
$\mathbf{4 .}$ & Pizza & 16 & 9 & \\
$\mathbf{5 .}$ & Grotesque & 7 & 18 \\
$\mathbf{6 .}$ & Genera & 9 & 16 \\
$\mathbf{7 .}$ & Of & 16 & 9 & \\
$\mathbf{8 .}$ & Chemise & 0 & 25 \\
$\mathbf{9 .}$ & Womb & 8 & 17 \\
$\mathbf{1 0}$ & Niche & 9 & 6 & \\
$\mathbf{1 1}$ & Chassis & 4 & 21 & \\
\hline
\end{tabular}




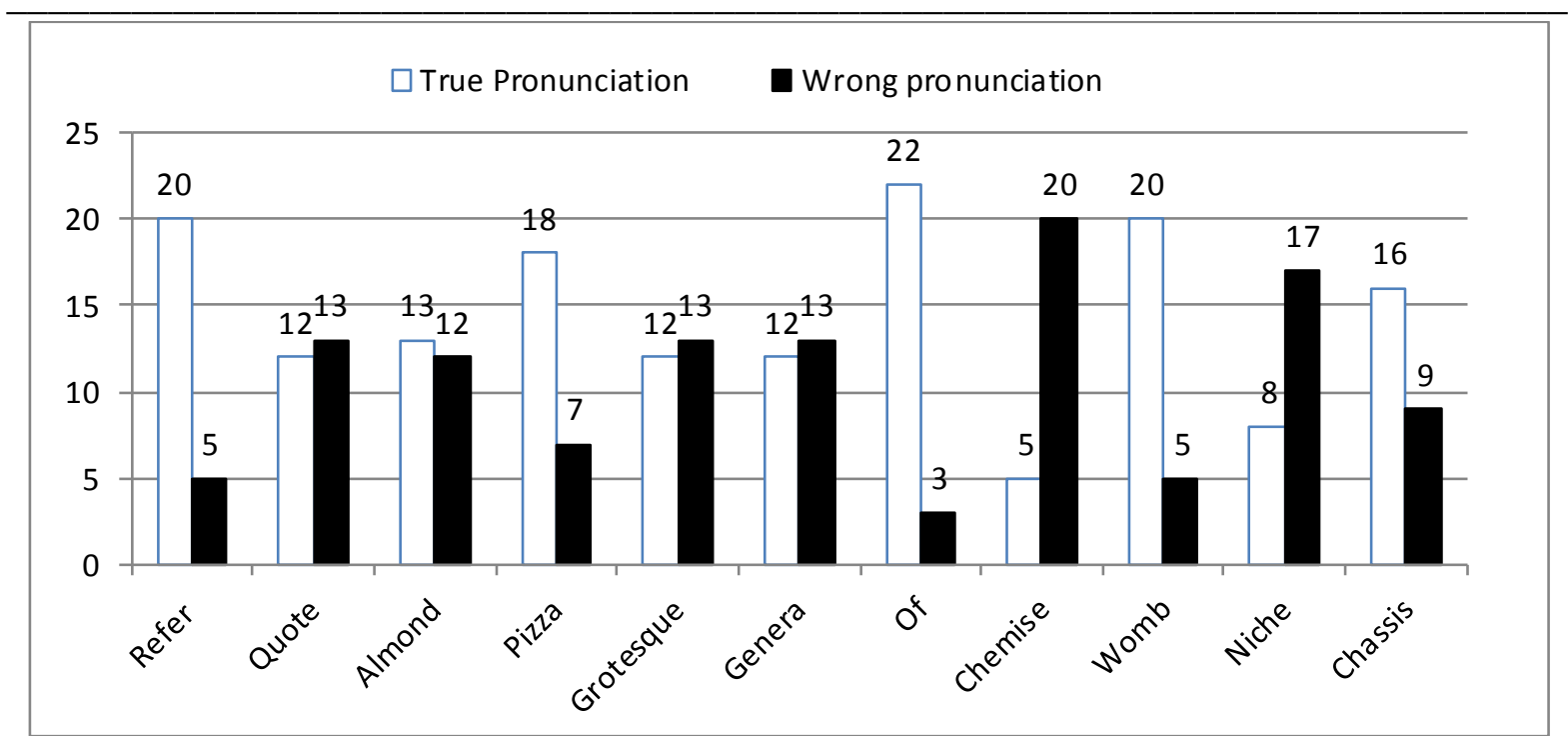

Figure-I, comparison of correct and wrong pronunciation of words by Bureaucrat.

Figure-I indicates the detailed insight regarding right and wrong pronunciation of prescribed words, which were randomly selected to check the pronunciation of bureaucrat class. The white column shows the right pronunciation, whereas, black column indicates the wrong pronunciation of the word.

Towards analysis, each word is presented graphically with two columns i.e. Right and Wrong. Here, it is important to note that the most mispronounced word by the bureaucrat is "Chemise", which is incorrectly pronounced by 20 participants. Contrary to it, the most true pronounced word is "Of", which is pronounced by 22 participants correctly. The second two correctly pronounced words are "Refer" and "Womb" as most of the participants quickly judged the phonological structure of the words. Actually, they are well in use of these words by true pronunciation, which makes them able to speak these words correctly. The third most correctly pronounced word is "Pizza". Instead of viral eating of pizza, most people are unaware of its actual pronunciation due to its physical and phonological difference. The forth corrected uttered word is "Chassis", it is correctly spoken by 16 participants. The word "Almond" comes in fifth. No doubt, it is one of my favourite, common and very hygienic dry fruits but it is also not safe from mispronunciation. "Genera" and "Quote" are the words, which come at sixth number with reference to correctly pronounced. The word "Quote" is, no doubt, well famous for using in regular communication, yet it goes mispronounced due to its little sound of /w/ generally, which may be said to be a hidden phoneme in word and it makes it complicated to pronounce it correctly. Whereas, the word "Genera" is not as common as "Quote" is, because it is specifically a word of biology. The seventh correctly pronounced word is "Grotesque", which is wrongly uttered by 18 candidates. Seventh right and second most wrongly pronounced word is "Niche", it is very complicated by the physical appearance to speak it correctly. The syllable "che" convinces the reader to speak it as $/ \mathrm{k} /$, however, true one is $/ \mathrm{J} /$.

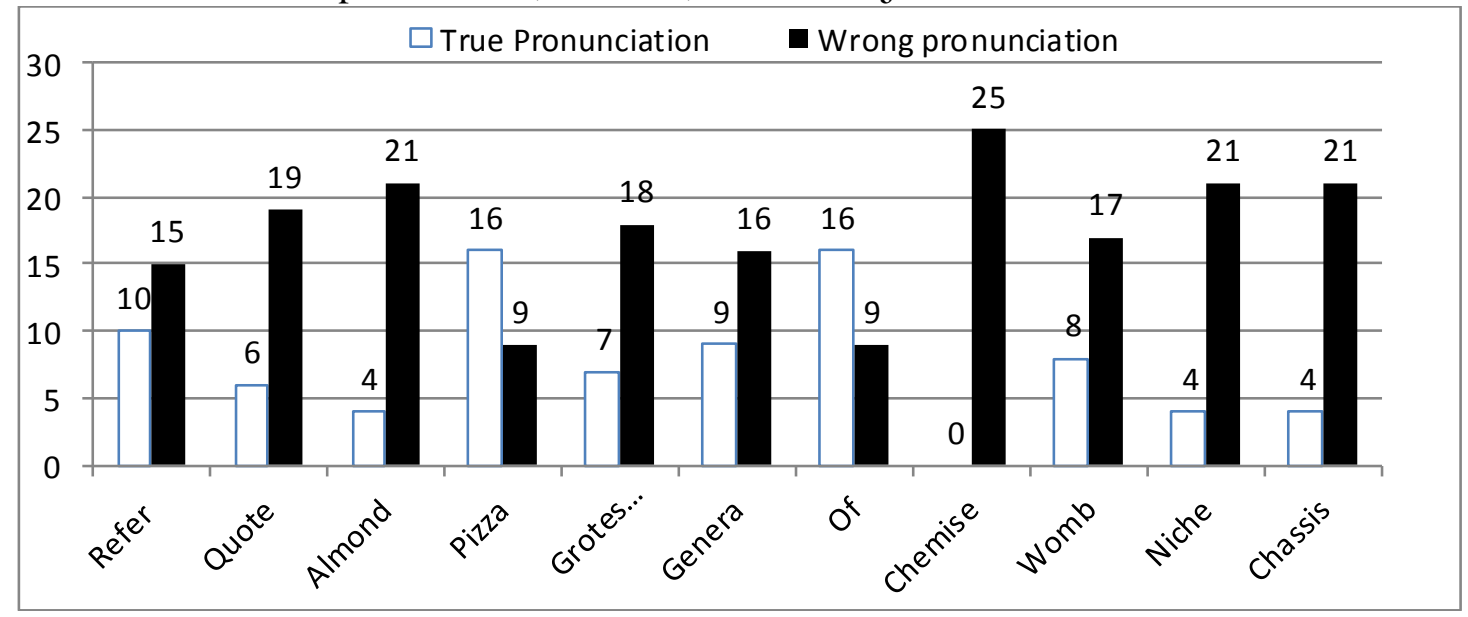

Figure-II, comparison of right and wrong pronunciation by 25 No. Engineers. 
Figure-II leads us to explore the status of pronunciation of English in Technocrat i.e. Engineers. Here, we found the top rightly pronounced words are "Pizza" and "Of", which are correctly pronounced by 19 participants out of 25 . The pizza is mispronounced by its physically hidden phoneme /t/ before /s/ sound. However, "Of" is only wrongly spoken due to /f/, which is actually $/ \mathrm{v} /$. The word "Refer" comes at the second stage, which is truly pronounced by 15 participants. It is apt to mention that the only error of this word is about $/ \mathrm{i} /$, which is spoken as /e/. Next or third one is "Genera", which is truly uttered by 9 participants out of 25. It is wrongly pronounced only due to its opening sound, which is /dj/ but it is wrongly uttered as /ge/. The fifth word is /Grotesque/, which is correctly uttered by 7 participants. The major error in the pronunciation is the diphthong /əu/ and it is wrongly uttered as /u/. The word, which comes at the sixth stage is "Quote". Here, it is again the trouble of hidden sound /w/, which is not recognized by the people usually due to lack of phonological structure of words. The word "Chassis" is wrongly said due to conflict between its physical and phonological structure. The most mispronounced words by the technocrats are "Chemise" \& "Niche". It is obvious that these are problematic words, which are very complicated to be correctly uttered due to their physical structures. "Chemise" is wrongly spoken as /kemaiz/ and "Niche" is incorrectly uttered as /nik/ \& /ni: $\mathrm{j} /$, whereas, true pronunciations of the both words are / $\int$ əmi:z/ and /ni: // respectively.

\section{Analysis of Open Ended Questions}

To know about the major reasons behind above quoted errors of speaking, an open-ended questionnaire was designed with lenient mood, in which, participant might go to detail or end with simple yes or no. following are the questions, which were used to inquire about the reasons of mispronunciation of words:

1. Does pronunciation matter in speaking English according to you?

2. Are you reluctant to correct your pronunciation, if yes, why?

3. Do you know about the phonological structure of words in English language?

4. Do you know; you speak the correct or standard English?

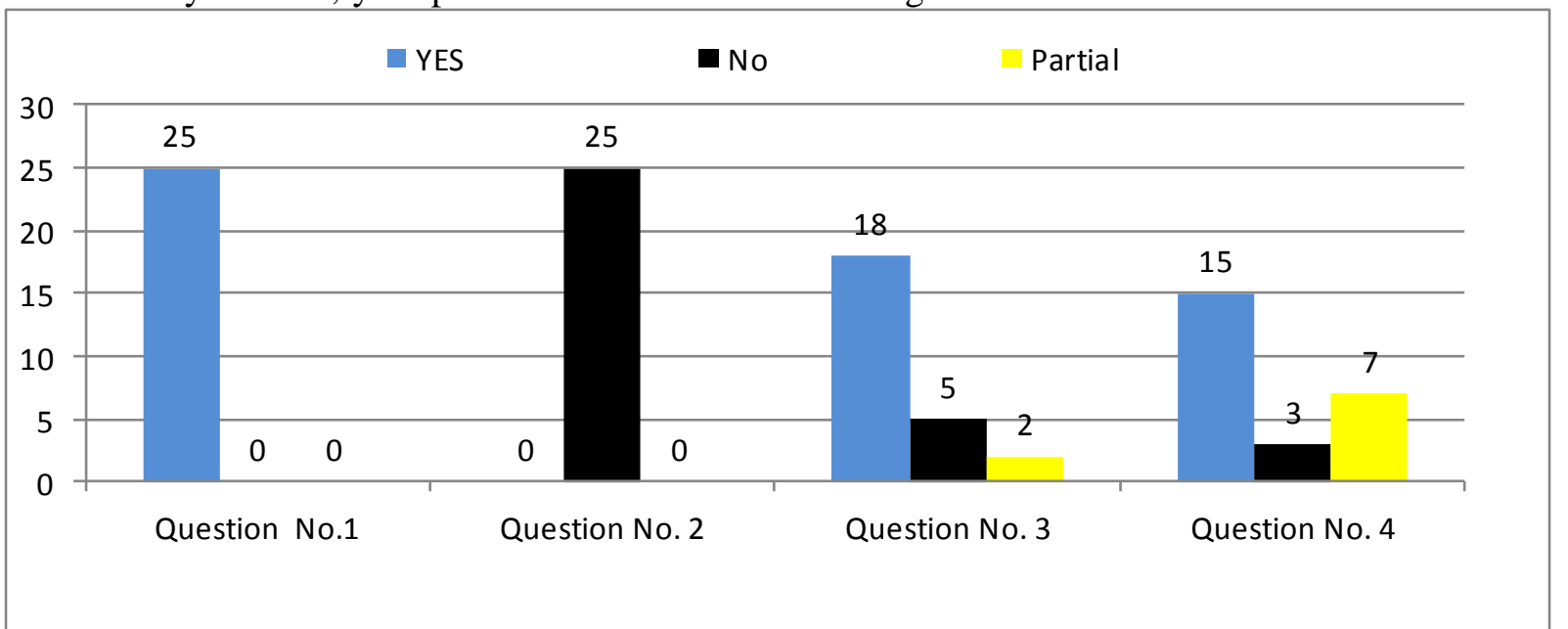

Figure-III analysis of open-ended questions of 25 bureaucrats.

Here, we go to analyse the data from open-ended questions on graphical as well as descriptive manner with the help of Figure-III. To go for analysis, the $1^{\text {st }}$ question indicates the general phenomenon or opinion towards pronunciation. Accordingly, the $100 \%$ result clearly indicates that pronunciation does matter. As far as the 2nd question is concerned, $100 \%$ are willing to correct their pronunciation, which shows a positive response. The 3rd question is important as it goes to know about the phonological structure of the word, which is mandatory to utter a word correctly. Here, it is observed that there are divisions among the participants with reference to their awareness about the internal part of a word to pronounce it in the correct manner. Out of 25 participants, 18 participants know the phonological structure and 5 participants do not know and only 2 candidates are partial about their knowledge in the matter. $4^{\text {th }}$ question goes to ask the first hand information about the how know of the candidate regarding their speaking skill, which, resultantly, let us know that, out of 25 participants, 15 participants claim that their speaking is as per standard, whereas, 3 participants do not know and 7 participants show their partial attitude towards the question. 


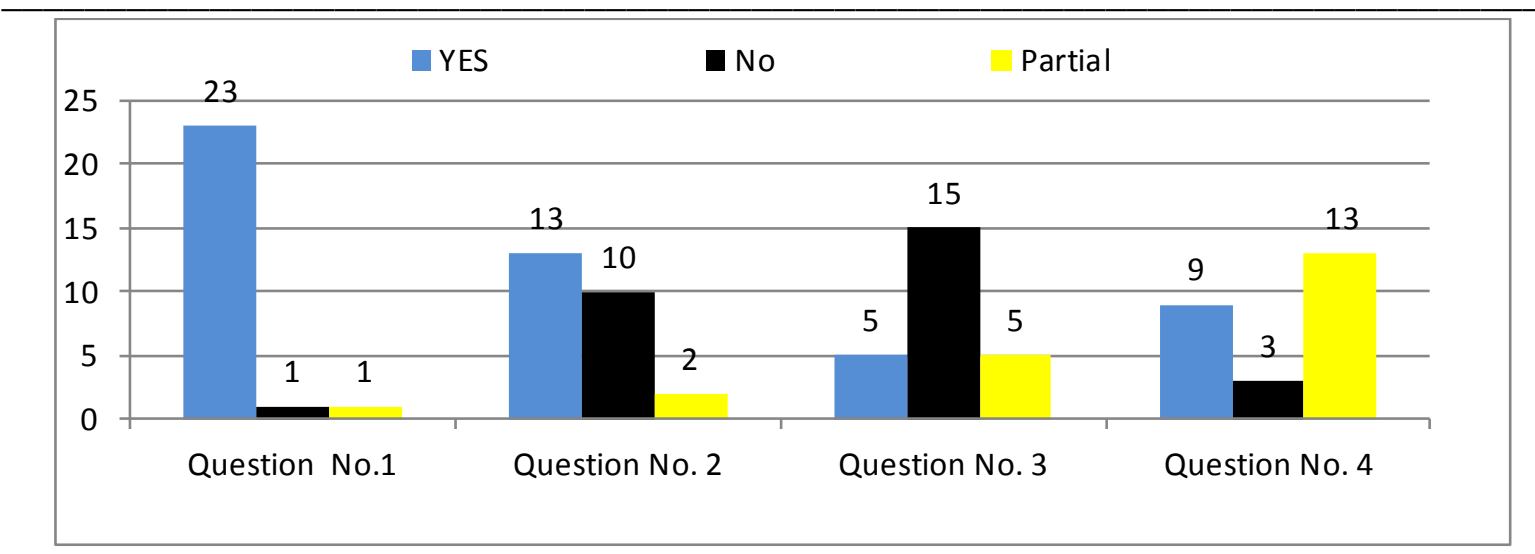

Figure-IV analysis of open-ended questions of 25 engineers.

Figure-IV is a graphical representation of above said open-ended 4 No. questions with the response from Engineers. The very first question explores before us the attitude of Engineers towards the importance of pronunciation, which shows that, out of 25,23 engineers are in favour of the importance of pronunciation. The 2nd question elaborates the attitude of Engineers towards correction of English pronunciation, which shows that, out of 25,13 candidates show their willingness to improve their pronunciation skill, 13 participants go to avoid such activity and 2 are ambiguous. The 3rd question goes in depth about the knowledge of words, which shows that 15 are unaware, 5 candidates are aware and 5 are partial about the phonological structure of a word. The last question asks them about their own information regarding their awareness about their own pronunciation. Which comes before us as 9 participants are well aware that they are sure about their true pronunciation, 3 participants do not know and 13 participants are partial in the matter.

COMPARATIVE ANALYSIS OF BUREAUCRAT AND TECHNOCRAT

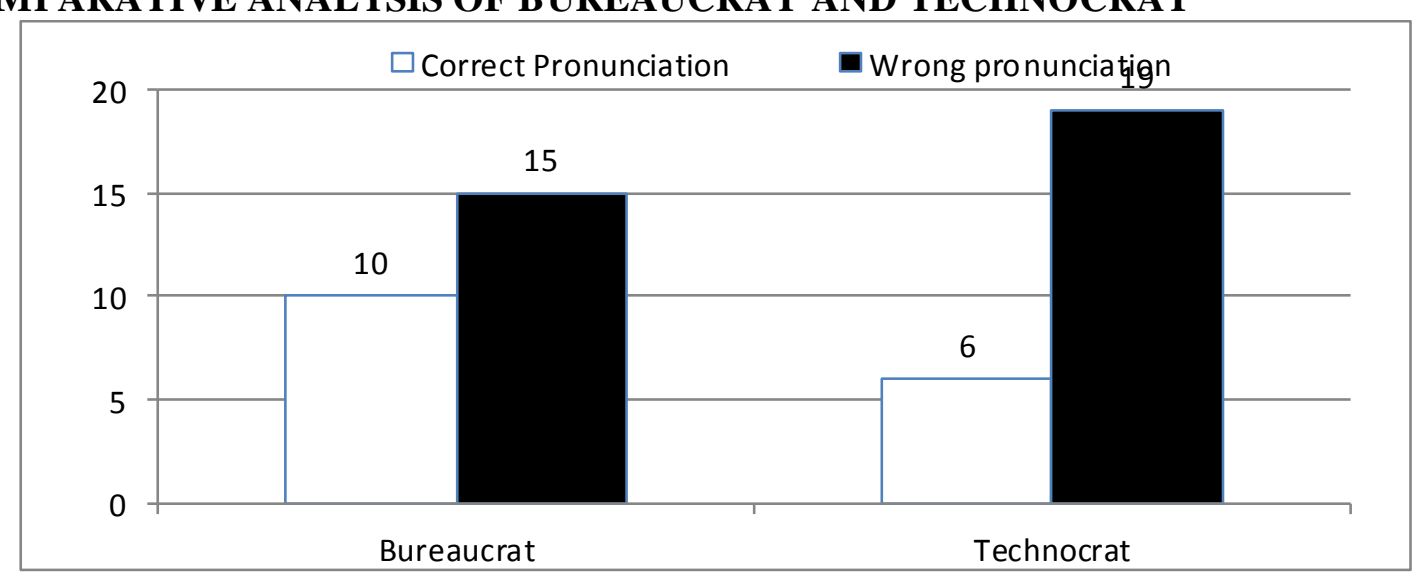

Figure- $\mathrm{V}$, comparative analysis of bureaucrat and engineer.

Figure- $\mathrm{V}$ figuratively shows the comparison of both types of population, which are bureaucrat and engineer on the basis of above said results of the quantitative observation sheet. The overall analysis leads to make Bureaucrat superior to Engineer because former is more correct than latter in pronunciation according to above explained findings.

Simultaneously, the critical overview of open-ended questions reveals to us that bureaucrats are more conscious about their English, especially, about speaking than engineers. It is, similarly, important that we cannot deny the fact one and other classes totally. Cumulative overview of openended questions convinces us that Bureaucrats are very conscious because they do not only use language but also try to correspond and communicate in true letter and spirit as per rules and regulations determined by English language. Bureaucrat is in the view that any language should be used as per its prevailing features and domain. However, on the other side of the rostrum, most technocrats go totally opposite of the views of the former because the latter believes that English language should be used only for the purpose of conveying and getting meaning without going deep into linguistic features of English language. According to analysis of their views on open-ended questions, Engineers are more comfortable with violating rule and regulation of English grammar and pronunciation because they opine that learning of linguistic features of English language derive them from their main purpose of study. They just learn English for a specific purpose. 


\section{Conclusion}

It is one of the important parts of any research, which deals with the crux of whole research work. To go ahead with this section, we observe the overall view of two types of population i.e. bureaucrat and engineer. Here, two of the major groups of our society, who are connected with administrative as well as development matters of our society, give us different two sides of the same coin. After consulting with data collected from them, it is crystal clear that both are on the different sides of the same stick but views of the both cannot be denied or rejected wholly. Because, we are not only confined with the close-ended structured questions but we also visit the views obtained from them through open-ended questions in order to know their attitude and reasons behind unawareness about correct pronunciation. Data from bureaucrats indicates a positive tone towards English language because bureaucrats are well willing to correct and improve their language. That's why, their focus also remains upon pronunciation skill. Simultaneously, engineers are aware of English but they are not too conscious to go in depth of English language. It is viewed by engineers that they use English language for a specific purpose, therefore, their use of language and its importance may depend upon the purpose. Because engineers are technical and they have to use language for improving and flourishing the engineering profession. Moreover, as observed by data from engineers, they consider English as a hurdle in the way of their success. That's why, they avoid going to the linguistic depth of English language, which is definitely too complex and sophisticated.

To go towards the conclusion, we may sum it up that English is, no doubt, a leading language in the world, that is why there is wide use of English language in Pakistan too. However, its importance varies from class to class and from person to person. Some people, like engineers, take it as the only source of learning or getting knowledge specifically without learning the true soul of English language. Whereas, some people like Bureaucrats take it as a source of development and superiority and keep abreast of all linguistic features. So, on behalf of available analysed data, we may not go in favour of one while opposing another. Because, both of the targeted classes have their personal interests and reasons for favouring and negating the pronunciation skill of English language.

\section{Recommendations}

Following are the recommendations of the research for learning better pronunciation of English:

1. It should be taught to students that learning of any language includes all of the components of that language i.e. grammar, vocabulary and pronunciation. Accordingly, these three parts are essential to any language and they must be focused equally.

2. Pronunciation should be focused from the initial level of teaching English language, so that it may not become a hurdle later.

3. Teachers should be well aware about the phonological structure and convince students to correct pronunciation from time to time.

4. Oral examination for testing pronunciation skill may be conducted from time to time as per schedule of written examination in order to improve pronunciation.

5. Digital dictionaries should be encouraged in order to learn correct pronunciation by the teacher.

\section{Reference}

Akram, M., \& Qureshi, A. H. (2014). The Role of Features of Connected Speech in Teaching English Pronunciation. International Journal of English and Education (Vol-3) , 230-240.

Aliaga García, C. (2007). The Role of Phonetic Training in L2 Speech Learning. Proceedings of the Phonetics Teaching and Learning Conference (PTLC2007), University College, London. Available at http://www.phon.ucl.ac.uk/ptlc/ptlc2007_web_procindex.html

Crystal, D. (1997). English as a global Language . Cambridge University Press.

Dan, C. (2006). How can I improve my student's pronunciation? Guyuan, Ningxia: China's Experimental Centre for Educational Action Research in Foreign Language Teaching.

Esmail, A., Ahmed, M., \& Noreen, S. (May 2015). Why do Pakistani students reluctant to speak English? Academic Research International (Vol-6(3)), 372-378.

Fraster, H. (2000). Coordinating improvements in pronunciation teaching.

James, R. B. (2010). Teaching Pronunciation Gets a Bad R.A.P: A Framework for Teaching Pronunciation. Hankuk: University of Foreign Studies.

Sharma, O. (2004). Principle of education. New Delhi: Deep and Deep Publication Pvt. Ltd. 